Original Articles

\title{
An integrated biomarker response study explains more than the sum of the parts: Oxidative stress in the fish Australoheros facetus exposed to imidacloprid
}

\author{
Fernando G. Iturburu ${ }^{\mathrm{a}}$, Lidwina Bertrand ${ }^{\mathrm{b}}$, Julieta R. Mendieta ${ }^{\mathrm{c}}$, María V. Amé ${ }^{\mathrm{b}}$, \\ Mirta L. Menone ${ }^{\text {a,* }}$ \\ a Laboratorio de Ecotoxicología, Instituto de Investigaciones Marinas y Costeras (IIMYC), Consejo Nacional de Investigaciones Científicas y Técnicas (CONICET) - \\ Universidad Nacional de Mar del Plata, Funes 3350, 7600 Mar del Plata, Buenos Aires, Argentina

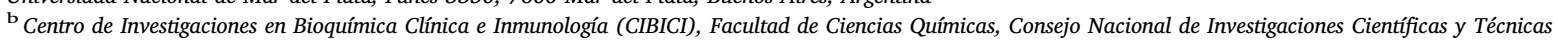 \\ (CONICET) - Universidad Nacional de Córdoba, Haya de la Torre esq., Medina Allende, 5000 Córdoba, Argentina \\ ${ }^{\mathrm{c}}$ Instituto de Investigaciones Biológicas, Facultad de Ciencias Exactas y Naturales, Consejo Nacional de Investigaciones Científicas y Técnicas (CONICET) - Universidad \\ Nacional de Mar del Plata, Funes 3250, 7600 Mar del Plata, Argentina
}

\section{A R T I C L E I N F O}

\section{Keywords:}

Neonicotinoid

Integrated biomarker response index

Antioxidant enzymes

Oxidative damage

Fishes

\begin{abstract}
A B S T R A C T
Integrated Biomarkers Response (IBR) index have been developed as a practical and robust tool to assess the susceptibility to pollutants using multiple biomarker responses. Neonicotinoid insecticides are nowadays one of the most sold pesticides worldwide. Nevertheless, imidacloprid (IMI) sub-lethal effects such as oxidative stress (OS) on fishes are scarcely studied. Hence, the aims of this work were: (1) to evaluate exposure- and damage biomarkers related to OS in the freshwater fish Australoheros facetus exposed to IMI and (2) to apply the IBR index to achieve a comprehensive understanding of OS in the fish. The results of the present study showed that all the biomarkers presented different responses in the three monitored tissues: liver, brain and gills. Results for an initial battery of 19 biomarkers were obtained and for the IBR index only those with significant differences have been considered. The biomarkers that had the most important weight on the IBR index were SOD activity in brain and gills, $\mathrm{H}_{2} \mathrm{O}_{2}$ concentration in liver, and carbonyl groups concentration in gills in fishes exposed to 100 and $1000 \mu \mathrm{g} \mathrm{L}^{-1}$ IMI. This index allowed affirming that a short term exposure to environmentally relevant concentrations of IMI ( $\geq 10 \mu \mathrm{g} \mathrm{L}^{-1}$ ) produces OS in A. facetus. However, a more deep understanding of some biomarkers response is necessary to improve the index and for finally apply it in field studies.
\end{abstract}

\section{Introduction}

The identification of ecological risks due to exposure of aquatic organisms to environmental pollutants is a crucial point for environmental managers. Nevertheless, the complexity of direct and indirect interactions among different ecosystem components in wild populations makes assessment of the impacts of environmental pollutants on aquatic species challenging (Santos et al., 2016). In this context, systematic assessment methods of potential risk of pollutants (i.e., pesticides) could serve as valuable tools in decision making and policy formulation (Kookana et al., 2005).

In the last 30 years the literature showed the use of different parameters able to explain effects of pollutants on different organisms (i.e., fish) at community or individual levels. To synthesize this information, different authors have developed a wide variety of indices and metrics used in biological monitoring (Revenga et al., 2005). In the case of fish communities, the index of biotic integrity (IBI) was developed in the 1980 decade (Karr, 1981). It is an ecological approach that incorporates multiple attributes of a fish community into a composite index predictive of water quality (Eaton and Lydy, 2000), successfully used in several studies (i.e., Scott and Hall, 1997). Later, Oberdorff et al. (2002) developed a modification called fish based index (FBI), a biological indicator which integrate environmental factors acting on fish assemblage structure in natural conditions able to distinguish effects of human-induced disturbances from natural variation.

Beyond these community indices, morphometric indices are used frequently to estimate fish general health (growth, nutritional state and energy content) under the assumption that morphometric changes track to physiological changes (Sutton et al., 2000). These kind of indices, like body condition indices or condition factors, are common indices in

\footnotetext{
* Corresponding author at: Funes 3350, 7600 Mar del Plata, Buenos Aires, Argentina.

E-mail address: mirta.menone@gmail.com (M.L. Menone).
} 
Table 1

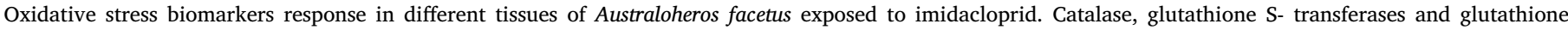

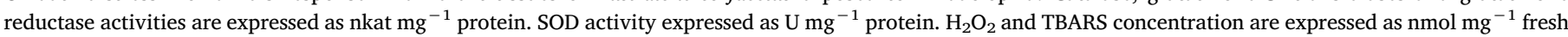

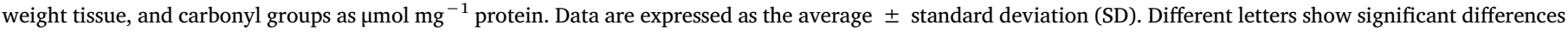
among treatments $(\mathrm{p}<0.05)$.

\begin{tabular}{|c|c|c|c|c|c|c|c|c|}
\hline \multirow[t]{2}{*}{ Biomarker } & \multirow[t]{2}{*}{ [IMI] $\left(\mu \mathrm{g} \mathrm{L}^{-1}\right)$} & \multicolumn{6}{|l|}{ Tissue } & \multirow[t]{2}{*}{ Tissue Difference } \\
\hline & & Liver & & Gills & & Brain & & \\
\hline \multirow[t]{5}{*}{ CAT } & 0 & $2575 \pm 471$ & $\mathrm{a}$ & $427.49 \pm 68.09$ & $\mathrm{a}$ & & & YES \\
\hline & 1 & $2767 \pm 640$ & $\mathrm{a}$ & $488.42 \pm 197.51$ & a & & & \\
\hline & 10 & $2628 \pm 547$ & $\mathrm{a}$ & $362.07 \pm 101.88$ & $\mathrm{a}$ & & & \\
\hline & 100 & $2602 \pm 936$ & $\mathrm{a}$ & $372.76 \pm 42.07$ & $\mathrm{a}$ & & & \\
\hline & 1000 & $2723 \pm 804$ & $\mathrm{a}$ & $250.77 \pm 26.31$ & $\mathrm{a}$ & & & \\
\hline \multirow[t]{5}{*}{ SOD } & 0 & $4204 \pm 384$ & $\mathrm{a}$ & $3034 \pm 307$ & $\mathrm{a}$ & $4156 \pm 470$ & $\mathrm{a}$ & YES \\
\hline & 1 & $4199 \pm 710$ & $\mathrm{a}$ & $2769 \pm 349$ & $\mathrm{a}$ & $4049 \pm 610$ & a & \\
\hline & 10 & $4129 \pm 191$ & $\mathrm{a}$ & $1161 \pm 45$ & $\mathrm{~b}$ & $3702 \pm 304$ & $a b$ & \\
\hline & 100 & $3870 \pm 458$ & $\mathrm{a}$ & $1077 \pm 151$ & $\mathrm{~b}$ & $3492 \pm 379$ & $\mathrm{~b}$ & \\
\hline & 1000 & $3296 \pm 381$ & $\mathrm{~b}$ & $739 \pm 60$ & $\mathrm{c}$ & $2968 \pm 264$ & $\mathrm{c}$ & \\
\hline \multirow[t]{5}{*}{ GST } & 0 & $14.75 \pm 3.87$ & $\mathrm{a}$ & $5.98 \pm 1.13$ & $\mathrm{a}$ & $2.10 \pm 0.63$ & a & YES \\
\hline & 1 & $12.99 \pm 1.61$ & $\mathrm{a}$ & $6.83 \pm 1.70$ & $\mathrm{a}$ & $2.10 \pm 0.49$ & $\mathrm{a}$ & \\
\hline & 10 & $13.22 \pm 2.50$ & $\mathrm{a}$ & $5.59 \pm 0.94$ & $\mathrm{a}$ & $2.27 \pm 0.48$ & $\mathrm{a}$ & \\
\hline & 100 & $13.43 \pm 4.34$ & $\mathrm{a}$ & $6.72 \pm 1.47$ & $\mathrm{a}$ & $1.91 \pm 0.66$ & $\mathrm{a}$ & \\
\hline & 1000 & $14.24 \pm 3.03$ & $\mathrm{a}$ & $7.15 \pm 2.41$ & a & $1.57 \pm 0.67$ & $\mathrm{a}$ & \\
\hline \multirow[t]{5}{*}{ GR } & 0 & $0.37 \pm 0.05$ & $\mathrm{a}$ & $2.56 \pm 0.63$ & $\mathrm{a}$ & & & YES \\
\hline & 1 & $0.34 \pm 0.21$ & $\mathrm{a}$ & $2.78 \pm 0.51$ & $\mathrm{a}$ & & & \\
\hline & 10 & $0.22 \pm 0.04$ & $\mathrm{a}$ & $2.41 \pm 0.37$ & $\mathrm{a}$ & & & \\
\hline & 100 & $0.30 \pm 0.09$ & $\mathrm{a}$ & $2.97 \pm 0.22$ & $\mathrm{a}$ & & & \\
\hline & 1000 & $0.38 \pm 0.10$ & $\mathrm{a}$ & $2.46 \pm 0.42$ & a & & & \\
\hline \multirow[t]{5}{*}{$\mathrm{H}_{2} \mathrm{O}_{2}$} & 0 & $1.15 \pm 0.05$ & $\mathrm{a}$ & $0.72 \pm 0.01$ & $\mathrm{a}$ & $0.83 \pm 0.03$ & $\mathrm{a}$ & YES \\
\hline & 1 & $1.01 \pm 0.06$ & $\mathrm{~b}$ & $0.72 \pm 0.02$ & $\mathrm{a}$ & $0.79 \pm 0.01$ & $\mathrm{~b}$ & \\
\hline & 10 & $1.00 \pm 0.02$ & $\mathrm{~b}$ & $0.72 \pm 0.01$ & $\mathrm{a}$ & $0.81 \pm 0.02$ & $a b$ & \\
\hline & 100 & $2.39 \pm 0.07$ & $\mathrm{c}$ & $0.73 \pm 0.01$ & $\mathrm{a}$ & $0.81 \pm 0.02$ & $\mathrm{~b}$ & \\
\hline & 1000 & $3.42 \pm 0.12$ & $\mathrm{~d}$ & $0.73 \pm 0.01$ & a & $0.80 \pm 0.01$ & $\mathrm{~b}$ & \\
\hline \multirow[t]{5}{*}{ TBARS } & 0 & $0.05 \pm 0.01$ & $\mathrm{a}$ & $0.06 \pm 0.02$ & a & $0.06 \pm 0.00$ & $\mathrm{a}$ & YES \\
\hline & 1 & $0.05 \pm 0.01$ & $\mathrm{a}$ & $0.07 \pm 0.02$ & a & $0.06 \pm 0.01$ & $\mathrm{a}$ & \\
\hline & 10 & $0.05 \pm 0.02$ & $\mathrm{a}$ & $0.07 \pm 0.02$ & $\mathrm{a}$ & $0.07 \pm 0.02$ & $\mathrm{a}$ & \\
\hline & 100 & $0.07 \pm 0.03$ & $\mathrm{a}$ & $0.10 \pm 0.02$ & $\mathrm{a}$ & $0.05 \pm 0.02$ & $\mathrm{a}$ & \\
\hline & 1000 & $0.06 \pm 0.02$ & a & $0.07 \pm 0.02$ & $\mathrm{a}$ & $0.10 \pm 0.01$ & $\mathrm{a}$ & \\
\hline \multirow[t]{5}{*}{ CG } & 0 & $0.014 \pm 0.002$ & a & $0.015 \pm 0.004$ & a & $0.014 \pm 0.005$ & a & YES \\
\hline & 1 & $0.012 \pm 0.005$ & a & $0.011 \pm 0.004$ & $\mathrm{a}$ & $0.016 \pm 0.004$ & $\mathrm{a}$ & \\
\hline & 10 & $0.013 \pm 0.005$ & a & $0.014 \pm 0.004$ & $\mathrm{a}$ & $0.015 \pm 0.006$ & $\mathrm{a}$ & \\
\hline & 100 & $0.009 \pm 0.002$ & $\mathrm{~b}$ & $0.011 \pm 0.004$ & a & $0.016 \pm 0.004$ & $\mathrm{a}$ & \\
\hline & 1000 & $0.012 \pm 0.002$ & a & $0.009 \pm 0.003$ & $\mathrm{~b}$ & $0.014 \pm 0.005$ & $\mathrm{a}$ & \\
\hline
\end{tabular}

pollution effect studies (i.e., Brodeur et al., 2017). More particularly, histopathological indices (Maggioni et al., 2012) and fish somatic indices that relate the weight of determined tissues (i.e. liver, spleen, gonads) with the total fish weight are able to show pollutants effects on fish (i.e., Guyón et al., 2016; Ballesteros et al., 2017). On the other hand, fish biomarkers are useful tools in several steps of the risk assessment process: effect, exposure and hazard assessment, risk characterization or classification, and monitoring the environmental quality of aquatic ecosystems (van der Ooost et al., 2003). However, data provided by this biomarker approach is difficult to interpret without an integrated overview that globally assesses the potential influence of the pollutant under study (Bertrand et al., 2016a). Hence, stress indices also have been developed from this type of parameters. A prominent example of them is the Integrated Biomarkers Response (IBR) index, which constitutes a practical and robust tool to assess the susceptibility to pollutants using multiple biomarker responses (Beliaeff and Burgeot, 2002; Serafim et al., 2012). Several studies used this index with field data (Damiens et al., 2007; Cravo et al., 2012; Pain-Devin et al., 2014), although it was also utilized as a promising tool to integrate and interpret responses measured in organisms exposed in laboratory experiments (Quintaneiro et al., 2015; Bertrand et al., 2016a).

Neonicotinoid insecticides are nowadays one of the most sold pesticides worldwide. These insecticides are applied as seed coating, leaf spray and soil drenches when used in crops (Bonmatin et al., 2015) and they act on the central nervous system of insects, interfering with neural transmission (Gibbons et al., 2015). The neonicotinoid imidacloprid (IMI) was first registered in France in 1991 (Sur and Stork,
2003) and after its patent expiration in 2006 products based on IMI have extended its application to a broader scale of use (Elbert et al., 2008). Its high water solubility $\left(610 \mathrm{mg} \mathrm{L}^{-1}\right.$ at $\left.20^{\circ} \mathrm{C}\right)$ and hydrophilicity (log Kow $=0.57$; IUPAC PPDB, 2017), make possible IMI movement through plant tissues by the sap; protecting crops from roots to shoots (Fossen, 2006). In addition, these physical- chemical characteristics increase the chances of environmental contamination via surface- runoff or drainage into areas adjacent to the crops (Botías et al., 2016). Moreover, when it is applied as a seed coating, more than $80 \%$ of the active ingredient enter to the soil and soil water, and could leach into aquatic ecosystems (Goulson, 2014). The concentration of IMI in freshwater ecosystems has been well recorded in different regions of the world. The range of concentrations goes from ng $\mathrm{L}^{-1}$ (Masiá et al., 2013) to a reported maximum of $320 \mu \mathrm{g} \mathrm{L}^{-1}$ (van Dijk et al., 2013).

Toxic acute effects of IMI on aquatic organisms often happen on aquatic insects or other invertebrates, or at least with concentrations with several orders of magnitude less than in vertebrates (Morrissey et al., 2015). Acute toxicity of IMI on fishes has been established in the order of $\mathrm{LC}_{50} 200 \mathrm{mg} \mathrm{L}^{-1}$ for model species (Tišler et al., 2009; Fossen, 2006). Nevertheless, IMI sublethal effects such as oxidative stress (OS) on fishes are scarcely studied. Traditionally, biomarkers of exposure (antioxidant enzymes) as well as biomarkers of damage (oxidation products) are evaluated for studying OS without an integration tool for these responses.

Hence, the aims of this study were: (1) to evaluate exposure- and damage- biomarkers related to OS in the Southamerican fish Australoheros facetus exposed to IMI and (2) to apply the IBR index to 
A

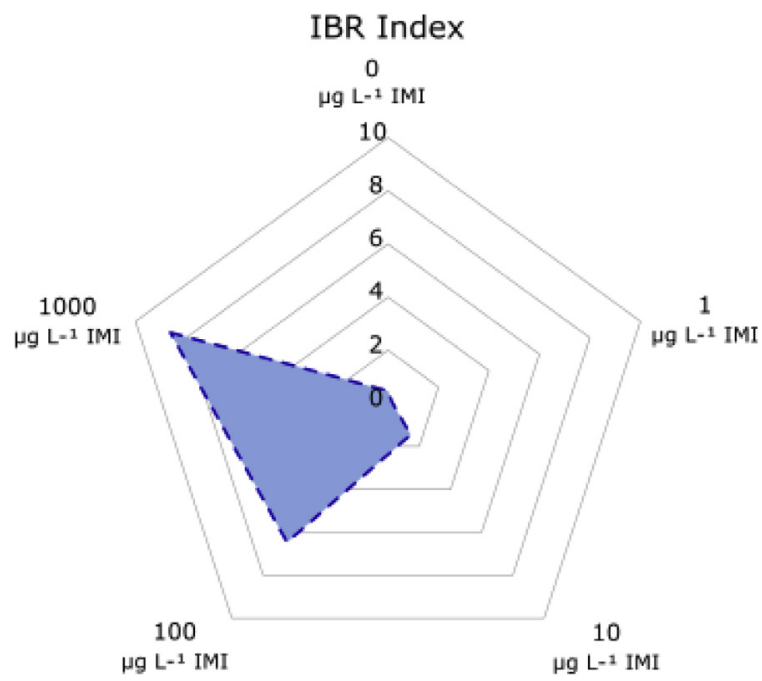

B

\begin{tabular}{lcccccc}
\hline \multicolumn{7}{c}{ IBR index } \\
\hline$[\mathbf{I M I}]\left(\boldsymbol{\mu g} \mathbf{L}^{-1}\right)$ & Median & & Mean & SD & Min & Max \\
\hline 0 & 0.19 & a & 0.47 & 0.45 & 0.00 & 1.13 \\
1 & 0.19 & a & 0.16 & 0.10 & 0.03 & 0.37 \\
10 & 1.41 & b & 1.46 & 0.36 & 0.82 & 2.11 \\
100 & 6.46 & c & 6.46 & 0.21 & 6.06 & 6.87 \\
1000 & 8.40 & d & 8.62 & 0.57 & 7.86 & 9.53 \\
\hline
\end{tabular}

Fig. 1. A: Radar graph for the calculated Integrated Biomarker Response (IBR) index for Australoheros facetus exposed to different concentrations $\left(\mu \mathrm{L} \mathrm{L}^{-1}\right)$ of imidacloprid (IMI) during $48 \mathrm{~h}$. The spokes of the radar indicate the IBR index mean values for each treatment. B: Median, mean, standard deviation (SD), minimal and maximal values for each treatment. Different letters indicate differences among treatments, analysed by non parametric pairwise comparisons following a Kruskal-Wallis Test $(\mathrm{p}<0.05)$.

achieve a comprehensive understanding of OS in the fish.

\section{Material and methods}

\subsection{Reagents and animals}

Imidacloprid (N-\{1-[(6-chloro-3-pyridyl) methyl]-4,5-dihydroimidazol-2-yl $\}$ nitramide) analytical standard (CAS No. 138261-413) and all reagents for biochemical biomarkers assays were obtained from Sigma-Aldrich.

Juvenile specimens of the cichlid fish Australoheros facetus were obtained from natural reservoirs located in the south-east region of Buenos Aires Province. Fishes were acclimatized for two months to laboratory condition in $140 \mathrm{~L}$ tanks $(12 \mathrm{~h}: 12 \mathrm{~h}$, light: dark photoperiod) to allow organisms to grow and to reach the assay size (block 1: $7.07 \pm 0.35 \mathrm{~cm}$; block 2: $6.78 \pm 0.44 \mathrm{~cm}$ ) and weight (block 1: $7.26 \pm 1.36 \mathrm{~g}$; block $2: 6.61 \pm 1.53 \mathrm{~g}$ ).

\subsection{Exposure conditions}

One bioassay was performed in two blocks because of the tissue amount necessary for determinations: the first for enzymes activity and $\mathrm{H}_{2} \mathrm{O}_{2}$ concentrations quantification, and the second one for lipid and protein oxidation. Six fish per treatment were exposed to 0 (negative control), 1, 10, 100 and $1000 \mu \mathrm{LL}^{-1}$ IMI for a period of $48 \mathrm{~h}$. Imidacloprid solutions were prepared by dissolution of IMI active ingredient in MilliQ water, and the solution were carried to the final concentration in tap water ( $\mathrm{pH} 8.5,15 \pm 1{ }^{\circ} \mathrm{C}$ water temperature). Exposures were carried out in static conditions, since previous experiments demonstrated that IMI has water stability at least until $48 \mathrm{~h}$ exposure (Iturburu et al., 2017). Fish were not feed during the exposure period to avoid any interference in the compound absorption. Negative control fish suffered the same handling than IMI exposed fish. After exposure fish were euthanized, and liver, gills and brain were withdrawn, frozen and stored at $-80^{\circ} \mathrm{C}$ until be processed.

\subsection{Biochemical biomarkers}

All biomarkers described below were measured in liver, gills and brain from six fish per treatment. Tissue extractions for enzymatic activities and hydrogen peroxide $\left(\mathrm{H}_{2} \mathrm{O}_{2}\right)$ concentration were carried out according to Wiegand et al. (2000) with modifications proposed by Cazenave et al. (2006). All biomarkers were determined in duplicate by spectrophotometry, using a Shimadtzu UV-210A (DOBLE-BEAM).

\subsubsection{Enzymatic activity measurements}

The activity of the soluble (cytosolic) glutathione S- transferases (GST) was determined using 1- chloro-2,4-dinitrobenzene (CDNB) as substrate, according to Habig et al. (1974). Glutathione reductase (GR) activity was measured according to Tanaka et al. (1994), quantifying the reduction of NADPH. Catalase (CAT) activity was assayed according with Claiborne (1985), measuring the decrease of $\mathrm{H}_{2} \mathrm{O}_{2}$ concentration. Superoxide dismutase (SOD) activity was assayed by the inhibition of nitro blue tetrazolium (NBT) reduction (Scebba et al., 1998). Activities of CAT, GST and GR were expressed as nkat $\mathrm{mg}^{-1}$ protein. SOD activity expressed as $\mathrm{U} \mathrm{mg}^{-1}$ protein.

\subsubsection{Hydrogen peroxide}

The $\mathrm{H}_{2} \mathrm{O}_{2}$ concentrations were measured by the FOX1 assay following Bellincampi et al. (2000). The method is based on the peroxidemediated oxidation of $\mathrm{Fe}^{2+}$, followed by the reaction of $\mathrm{Fe}^{3+}$ with xylenol orange. Results were expressed in $\mathrm{nmol} \mathrm{mg}^{-1}$ fresh weight tissue.

\subsubsection{Lipid peroxidation}

Lipid peroxidation was assayed by measuring the formation of thiobarbituric acid reactive substances (TBARS) following the methodology proposed by Oakes \& Van Der Kraak (2003). As 99\% of TBARS is malondialdehyde (MDA, Aydin, 2011), TBARS concentration of the samples was calculated by using the extinction coefficient of MDA, which is $1.56 \times 10^{5} \mathrm{M} \mathrm{cm}^{-1}$. Results were expressed in $\mathrm{nmol} \mathrm{mg}^{-1}$ fresh weight tissue.

\subsubsection{Determination of carbonyl groups in proteins}

Protein oxidation was assayed quantifying carbonyl groups (CG) formation according to Caballero et al. (2011). The method is based in the quantification of the incorporation of dinitrophenylhydrazine, using an average absorption of $21 \mathrm{mM} \mathrm{cm}^{-1}$ for aliphatic hydrazones for the calculation. Results were expressed in $\mu \mathrm{mol} \mathrm{mg}^{-1}$ protein.

\subsubsection{Protein concentration}

The total protein concentration was determined both for enzymatic activities/ $\mathrm{H}_{2} \mathrm{O}_{2}$ extracts and for CG extracts. For each sample, proteins were quantified by spectrophotometry according to Bradford (1976), using bovine serum albumin solution as standard.

\subsection{Data analysis}

\subsubsection{Integrated biomarker response}

One general stress index, termed "Integrated Biomarker Response", was calculated with biomarkers measured in Australoheros facetus. Results for an initial battery of 19 biomarkers were obtained to assess short term responses of exposed organisms. Only biomarkers with 


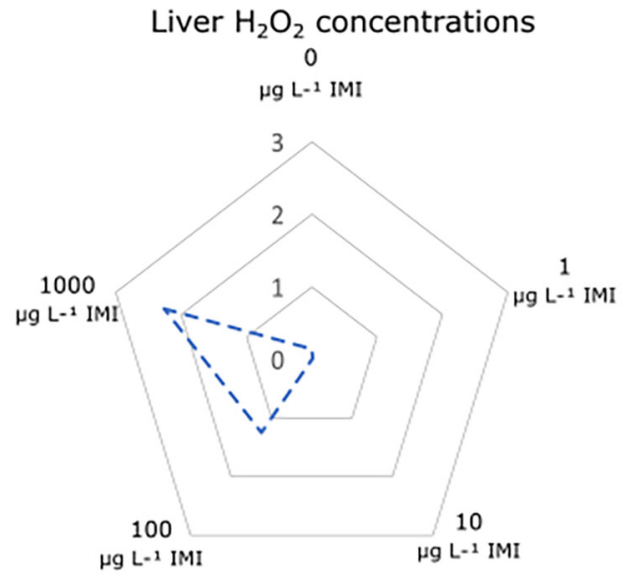

Gills carbonyl groups

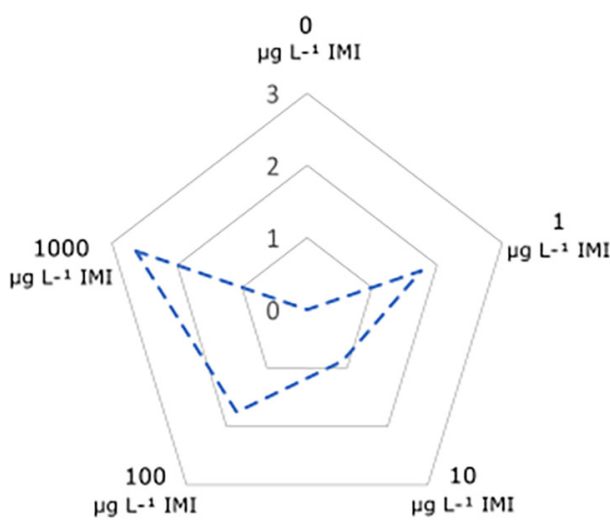

Brain SOD activity

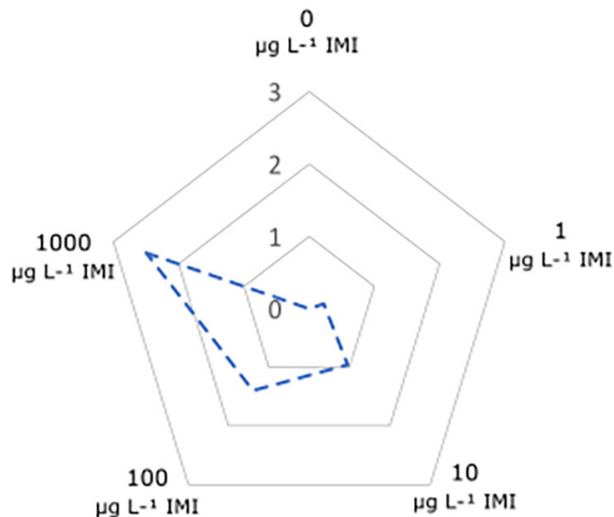

Brain $\mathrm{H}_{2} \mathrm{O}_{2}$ concentrations

0

$\mu g$ L-1 $1 M I$

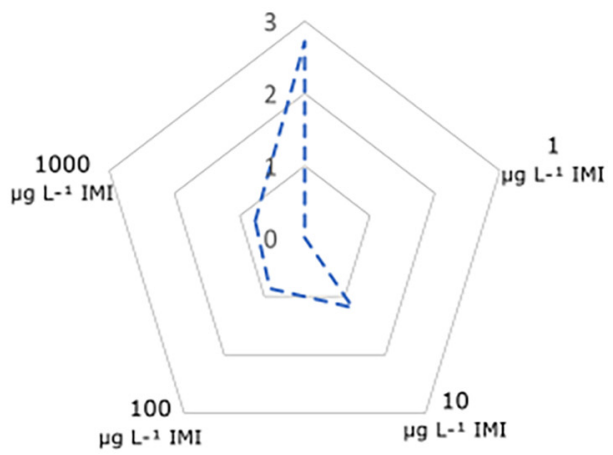

Liver carbonyl groups

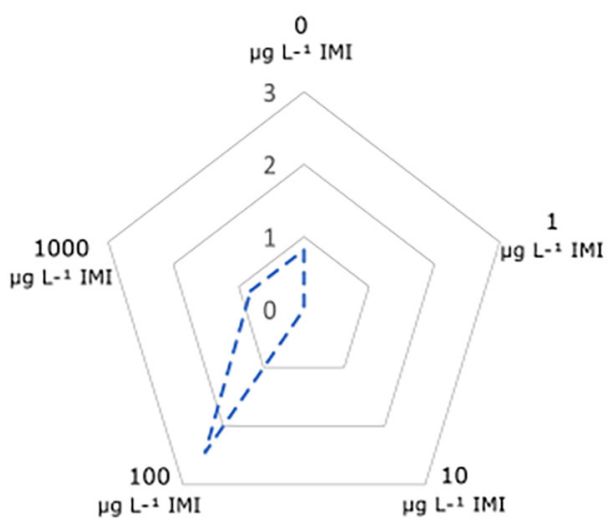

Gills SOD activity

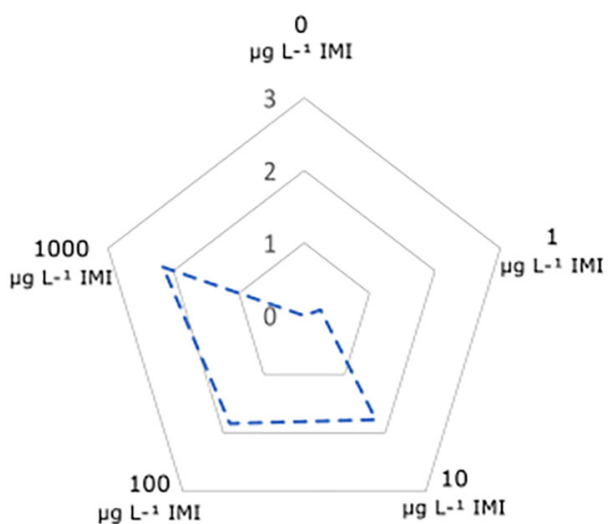

Fig. 2. Weight (standardized value, S) of considered biomarkers used to calculate the Integrated Biomarker Response (IBR) index for Australoheros facetus exposed during $48 \mathrm{~h}$ to different treatments: 0 (Control), 1, 10, 100 and $1000 \mu \mathrm{g} \mathrm{L}^{-1}$ of imidacloprid (IMI). The spokes of the radar indicate the $S$ value for each treatment.

significant differences between treatments have been considered and we excluded variables with strong correlation to keep non-redundant biological responses. In our case of study, the biomarkers used were: both carbonyl groups and $\mathrm{H}_{2} \mathrm{O}_{2}$ concentrations in liver and brain; and SOD activity in brain and gills.

The IBR index was performed in accordance to Bertrand et al. (2016a) using R Studio. Briefly, the mean value $\left(\mathrm{X}_{\mathrm{i}}\right)$, the general mean $\left(\mathrm{m}_{\mathrm{i}}\right)$ and standard deviation $\left(\mathrm{SD}_{\mathrm{i}}\right)$ for each biomarker at each exposure condition were calculated. The value $X_{i}$ was then standardized to obtain $Y_{i}$, where $Y_{i}=\left(X_{i}-m_{i}\right) / S D_{i}$. Subsequently, $Z_{i}=-Y_{i}$ or $Z_{i}=Y_{i}$ were computed in the case of a biological effect corresponding, respectively to inhibition or activation. The minimum value $\left(\min _{\mathrm{i}}\right)$ of $\mathrm{Z}_{\mathrm{i}}$ for each biomarker was obtained for each exposure condition. Finally, the score $S$ was calculated as $S_{i}=Z_{i}+\left|\min _{i}\right|$, where $\left|\min _{i}\right|$ is the absolute value. These $S$ values thus represent the gradient of values for each biomarker in the different exposure conditions, with highest values corresponding to the highest biological effects. The integrated biomarker response for each condition was calculated via the following formula:

$I B R=S 1 * \frac{S 2}{2}+S 2 * \frac{S 3}{2}+\ldots S n-1 * \frac{S n}{2}+S n * \frac{S 1}{2}$

in which the obtained score for each biomarker $\left(\mathrm{S}_{\mathrm{i}}\right)$ is multiplied with 
the score of the next biomarker $\left(S_{i+1}\right)$, arranged as a set, dividing each calculation by 2 and adding-up of all values.

Several IBR indices were calculated from the same data changing the order of the biomarkers and using the median of all the index values as the final index value (Devin et al., 2014).

\subsubsection{Statistical treatment}

Generalized Linear Mixed Model was used for the statistical analysis. Models were fitted, normality and variance homogeneity were tested, and variance function was applied when necessary. An a posteriori test (LSD Fisher with the corresponding Bonferroni errors correction) was used to determine significant differences between the means of control and other treatments $(\mathrm{p}<0.05)$. R Studio (Version 0.99.903) and Infostat (Version 2013p, Di Rienzo et al., 2013) were used for all statistical analyzes. A Kruskall Wallis test was carried out to identify IBR difference between treatments.

\section{Results and discussion}

\subsection{Biomarkers responses}

The effects associated to a possible OS process caused by IMI have been studied more deeply in terrestrial (i.e., Kapoor et al., 2011; ElGendy et al., 2010) than in aquatic animals. All the studied biomarkers in $A$. facetus exposed to IMI showed different responses in the three monitored tissues (Table 1). This tissue- specific responses have been reported for OS related biomarkers in other fish exposed to physical (i.e. high temperature, Madeira et al., 2016) or chemical stress (Oruç and Usta, 2007).

The $\mathrm{H}_{2} \mathrm{O}_{2}$ concentration increased in liver when fishes were exposed from 100 to $1000 \mu \mathrm{g} \mathrm{L}^{-1}$ IMI, while these concentrations decreased in brain at the same or even lower IMI concentrations ( $p<0.05$, Table 1). Nevertheless, $\mathrm{H}_{2} \mathrm{O}_{2}$ concentration did not change in gills at any IMI concentration ( $p>0.05$, Table 1$)$. The activity of SOD decreased in liver of $A$. facetus when exposed to $1000 \mu \mathrm{g} \mathrm{L}^{-1}$, in gills when the fishes were exposed from 10 to $1000 \mu \mathrm{g} \mathrm{L}^{-1}$ and in brain at 100 and $1000 \mu \mathrm{L} \mathrm{L}^{-1}$ IMI $(\mathrm{p}<0.05$, Table 1$)$.

This kind of response in liver (decrease of SOD activity and increase of $\mathrm{H}_{2} \mathrm{O}_{2}$ concentration) has been previously reported in $A$. facetus when exposed to the organochlorine pesticide endosulfan (Crupkin et al., 2013). The observed decrease in liver SOD activity may be explained by a negative feedback related with the high concentrations of $\mathrm{H}_{2} \mathrm{O}_{2}$ in this tissue (Sandalio et al., 2001). Other possible processes could be involved, like a decrease of de novo synthesis of enzyme proteins (Mishra et al., 2006) including SOD molecules; or oxidative damage in the active site of the enzyme protein (Hodgson \& Fridovich, 1975; Pigeolet et al., 1990). Regarding brain, and taking into account that SOD activity could produce $\mathrm{H}_{2} \mathrm{O}_{2}$ by the dismutation of superoxide radical (McCord and Fridovich, 1969), the decrease of SOD activity in this tissue could explain the decrease of $\mathrm{H}_{2} \mathrm{O}_{2}$ concentration in this tissue. Although $\mathrm{H}_{2} \mathrm{O}_{2}$ concentration did not change in gills of fish exposed to IMI, other ROS species could elicit a decrease of SOD activity in this tissue by oxidative damage to the active site of the enzyme as described above.

Catalase activity did not show significant changes in any of the studied tissues ( $\mathrm{p}>0.05$, Table 1 ). Although it has been reported that CAT could be a more sensitive biomarker than SOD in teleost fish (Vutukuru et al., 2006), our results showed that SOD was the most sensitive enzyme when fish was exposed to different concentrations of IMI.

Enzymatic activities of GST and GR did not show significant differences when fishes were exposed to tested IMI concentrations ( $p>0.05$, Table 1). Although Casida (2011) has described that glutathione could be involved in phase II IMI metabolism in mice and spinach, fish metabolism of IMI is not already enough studied. Indeed, the lack of change in the enzymatic activities of GST and GR seems to show that glutathione conjugation was not a detoxification pathway for
IMI in fish. Similarly to A. facetus, in the water flea Daphnia magna exposed $48 \mathrm{~h}$ from 10 to $40 \mathrm{mg} \mathrm{L}^{-1}$ IMI, the authors did not find any change in enzymatic activities of GST and CAT (Tišler et al., 2009). In A. facetus, despite the increase in $\mathrm{H}_{2} \mathrm{O}_{2}$ levels the enzymes analyzed did not increased their activities as protective systems. This could be due to non-enzymatic antioxidant mechanisms able to neutralize ROS compounds and not measured in the present study.

On the other hand, it has been described that GST activity could conjugate glutathione to inactivate highly reactive aldehydes produced from lipid peroxyl radicals (West and Marnett, 2006). In A. facetus exposed to IMI during $48 \mathrm{~h}$ this type of aldehydes did not seem to be produced, as shown by TBARS content in tissues monitored, which did not show differences respect to the control ( $p>0.05$, Table 1 ). Otherwise, there was a decrease of carbonyl groups in liver and gills at high IMI concentrations (100 and $1000 \mu \mathrm{g} \mathrm{L}{ }^{-1}$, respectively; $\mathrm{p}<0.05$, Table 1). We hypothesize that this decrease could be indicating a possible protein replacement because of an OS process. While total protein concentration was not affected with IMI treatments in any of the studied tissues (data not shown), protein turnover could be taking place, with a replacement of oxidized proteins with de novo synthesized ones. Dondero et al. (2010) found that the most evident molecular effect of IMI exposure on the marine mussel Mytilus galloprovincialis was that related to the increased of mRNA levels of 14 genes involved in protein translation. On the other hand, there was a record of protein levels increase by exposure to the neonicotinoid insecticide thiamethoxam in liver of the fish Oreochromis niloticus (Nath et al., 2012). Lipid peroxidation was detected in the amphipod crustacean Gammarus fossarum exposed to $102.2 \mu \mathrm{g} \mathrm{L}^{-1}$ IMI during $24 \mathrm{~h}$, while an increase of CAT and GST activities occurred at higher IMI concentrations (Malev et al., 2012). Therefore, species sensitivity deserves a more deep attention.

Regarding oxidative stress in fish exposed to IMI, in zebrafish (Danio rerio) SOD and GST increased its activities after 7 days exposure, but these activities decreased to a clear inhibition when the exposure time reached 28 days (Ge et al., 2015). Catalase activity only increased at 7 days, and ROS levels were increased at 1.25 and $5 \mathrm{mg} \mathrm{L}^{-1}$ IMI, to all evaluated times. Besides, these high IMI concentrations increased the MDA content after 21 days of exposure, as well as the DNA damage of time- and concentration- response (Ge et al., 2015).

\subsection{Integrated biomarker response}

As we can observe in the previous section, biomarkers responses not always are clear and easy to interpret because of their different patterns. Moreover, different responses in closely related species are common. Although the IBR index is a general stress index, in the present study a battery of biomarkers related to OS were chosen in order to explore if this process occurs in fishes exposed to IMI. Therefore, the IBR index was calculated using selected biomarkers in a way of integrating responses and facilitate their interpretation. The obtained values of IBR are shown in Fig. 1.

A significant increase of IBR values were observed from $10 \mu g \mathrm{~L}^{-1}$ IMI to the higher exposure concentrations, being significantly different from the control. According to these results, A. facetus exposed to concentrations of $10-1000 \mu \mathrm{g} \mathrm{L}^{-1}$ IMI during $48 \mathrm{~h}$ suffered increased levels of stress respect to control organisms. Besides, the results show the capacity of tested organisms to respond to environmentally relevant concentrations of IMI, supporting the usefulness of $A$. facetus as bioindicator of IMI pollution, at least for the range of concentrations $\geq 10 \mu \mathrm{g} \mathrm{L}^{-1}$ IMI. Taking into account standardized value (S) it is possible to identify which biomarkers had the most important weight on the final IBR values (Fig. 2) for tested conditions. Among the six selected biomarkers, SOD activity in brain and gills, $\mathrm{H}_{2} \mathrm{O}_{2}$ concentration in liver, and carbonyl groups concentration in gills were the most responsive biomarkers at the higher exposure concentrations (100 and $\left.1000 \mu \mathrm{g} \mathrm{L}^{-1} \mathrm{IMI}\right)$.

Despite the fact that in the last years there was an increase of the use 
of IBR indices both in plant and animals in laboratory experiments (Bertrand et al., 2016b, 2017) or field studies (Santos et al., 2016), few of them are applied for defining processes or modes of toxicity. For example, for mussels IBR indices were developed for inmunotoxical (Auffret et al., 2006) and lysosomal biomarkers (Izagirre and Marigomez, 2009) to evaluate contaminated sites. In the present study IBR indices allowed us to define OS caused by imidacloprid, an effect suspected but not well characterized in fishes exposed to IMI.

\section{Conclusions}

The present study used an IBR index to evaluate OS levels suffered by $A$. facetus exposed to IMI from a multi-tissue perspective. The integrative analysis of the present results allows us to affirm that a short term exposure to environmentally relevant concentrations of IMI $\left(\geq 10 \mu \mathrm{g} \mathrm{L}^{-1}\right.$ ) produces significant OS levels in A. facetus. In particular, biomarkers associated with oxidative stress, including SOD activity, $\mathrm{H}_{2} \mathrm{O}_{2}$ and carbonyl group concentrations, revealed to be those biochemical responses with higher weight in exposed organism. At last, a more deep understanding of some biomarkers response included in this study as well as to explore new biomarkers is necessary to improve the index and for finally apply it in field studies.

\section{Acknowledgments}

The present study was supported by UNMdP (EXA 702/14 and EXA 795/16) and FonCyT (PICT 2013-1348). Thank you to Dr. D. Garanzini for the picture used in the graphical abstract.

\section{References}

Auffret, M., Rousseau, S., Boutet, I., Tanguy, A., Baron, J., Moraga, D., Duchemin, M., 2006. A multiparametric approach for monitoring immunotoxic responses in mussels from contaminated sites in Western Mediterranea. Ecotoxicol. Environ. Safe. 63 (3), 393-405.

Aydin, B., 2011. Effects of thiacloprid, deltamethrin and their combination on oxidative stress in lymphoid organs, polymorphonuclear leukocytes and plasma of rats. Pest Biochem. Physiol. 100 (2), 165-171.

Ballesteros, M.L., Rivetti, N.G., Morillo, D.O., Bertrand, L., Amé, M.V., Bistoni, M.A., 2017. Multi-biomarker responses in fish (Jenynsia multidentata) to assess the impact of pollution in rivers with mixtures of environmental contaminants. Sci. Total Environ. 595, 711-722.

Beliaeff, B., Burgeot, T., 2002. Integrated Biomarker Response: a useful tool for eco-logical risk assessment. Environ. Toxicol. Chem. 21, 1316-1322.

Bellincampi, D., Dipierro, N., Salvi, G., Cervone, F., De Lorenzo, G., 2000. Extracellular $\mathrm{H}_{2} \mathrm{O}_{2}$ induced by oligogalacturonides is not involved in the inhibition of the auxinregulated rolB gene expression in tobacco leaf explants. Plant Physiol. 122 (4), 1379-1385.

Bertrand, L., Monferrán, M.V., Mouneyrac, C., Bonansea, R.I., Asis, R., Amé, M.V., 2016a. Sensitive biomarker responses of the shrimp Palaemonetes argentinus exposed to chlorpyrifos at environmental concentrations: Roles of alpha-tocopherol and metallothioneins. Aquat. Toxicol. 179, 72-81.

Bertrand, L., Asis, R., Monferrán, M.V., Amé, M.V., 2016b. Bioaccumulation and biochemical response in South American native species exposed to zinc: Boosted regression trees as novel tool for biomarkers selection. Ecol. Indic. 67, 769-778.

Bertrand, L., Marino, D.J., Monferrán, M.V., Amé, M.V., 2017. Can a low concentration of an organophosphate insecticide cause negative effects on an aquatic macrophyte? Exposure of Potamogeton pusillus at environmentally relevant chlorpyrifos concentrations. Environ. Exp. Bot. 138, 139-147.

Bonmatin, J.M., Giorio, C., Girolami, V., Goulson, D., Kreutzweiser, D.P., Krupke, C., Liess, M., Long, E., Marzaro, M., Mitchell, E.A.D., Noome, D.A., Simon-Delso, N., Tapparo, A., 2015. Environmental fate and exposure; neonicotinoids and fipronil. Environ. Sci. Poll. Res. 22 (1), 35-67.

Botías, C., David, A., Hill, E.M., Goulson, D., 2016. Contamination of wild plants near neonicotinoid seed-treated crops, and implications for non-target insects. Sci. Tot. Environ. 566-567(October), 269-278.

Bradford, M.M., 1976. A rapid and sensitive method for the quantification of micro-gram quantities of proteins utilizing the principle of protein-dye binding. Anal. Biochem. $72,248-254$.

Brodeur, J.C., Sanchez, M., Castro, L., Rojas, D.E., Cristos, D., Damonte, M.J., Poliserpi, M.B., D'Andrea, M.F., Andriulo, A.E., 2017. Accumulation of current-use pesticides, cholinesterase inhibition and reduced body condition in juvenile one-sided livebearer fish (Jenynsia multidentata) from the agricultural Pampa region of Argentina. Chemosphere 185, 36-46.

Caballero, V.J., Mendieta, J.R., Giudici, A.M., Crupkin, A.C., Barbeito, C.G., Ronchi, V.P., Chisari, A.N., Conde, R.D., 2011. Alternation between dietary protein depletion and normal feeding cause liver damage in mouse. J. Physiol. Biochem. 67 (1), 43-52.

Casida, J.E., 2011. Neonicotinoid metabolism: Compounds, substituents, pathways, enzymes, organisms, and relevance. J. Agr. Food Chem. 59 (7), 2923-2931.

Cazenave, J., Bistoni, M.A., Pesce, S.F., Wunderlin, D.A., 2006. Differential detoxification and antioxidant response in diverse organs of Corydoras paleatus experimentally exposed to microcystin-RR. Aquat. Toxicol. 76 (1), 1-12.

Claiborne, A., 1985. Catalase activity. In: Greenwald, R.A. (Ed.), CRC Handbook of Methods in Oxygen Radical Research. CRC Press, Boca Raton, FL, USA, pp. 283-284.

Cravo, A., Pereira, C., Gomes, T., Cardoso, C., Serafim, A., Almeida, C., Rocha, T., Lopes, B., Company, R., Medeiros, A., Norberto, R., Pereira, R., Araújo, O., Bebianno, M.J., 2012. A multibiomarker approach in the clam Ruditapes decussatus to assess the impact of pollution in the Ria Formosa lagoon, South Coast of Portugal. Mar. Environ. Res. 75, 23-34.

Crupkin, A.C., Carriquiriborde, P., Mendieta, J., Panzeri, A.M., Ballesteros, M.L., Miglioranza, K.S.B., Menone, M.L., 2013. Oxidative stress and genotoxicity in the South American cichlid, Australoheros facetus, after short-term sublethal exposure to endosulfan. Pest. Biochem. Physiol. 105 (2), 102-110.

Damiens, G., Gnassia-Barelli, M., Loquès, F., Roméo, M., Salbert, V., 2007. Integrated biomarker response index as a useful tool for environmental assessment evaluated using transplanted mussels. Chemosphere 66, 574-583.

Devin, S., Burgeot, T., Giambérini, L., Minguez, L., Pain-Devin, S., 2014. The integrated biomarker response revisited: optimization to avoid misuse. Environ. Sci Poll. Res. 21, 1-14.

Di Rienzo, J.A., Casanoves, F., Balzarini, M.G., Gonzalez, L., Tablada, M., Robledo, C.W., 2013. InfoStat versión 2013. Grupo InfoStat, FCA, Universidad Nacional de Córdoba, Argentina http://www.infostat.com.ar.

Dondero, F., Negri, A., Boatti, L., Marsano, F., Mignone, F., Viarengo, A., 2010. Transcriptomic and proteomic effects of a neonicotinoid insecticide mixture in the marine mussel (Mytilus galloprovincialis, Lam.). Sci. Tot. Environ. 408(18), 3775-3786.

Eaton, H.J., Lydy, M.J., 2000. Assessment of water quality in Wichita, Kansas, using an index of biotic integrity and analysis of bed sediment and fish tissue for organochlorine insecticides. Arch. Environ. Contam. Toxicol. 39 (4), 531-540.

Elbert, A., Haas, M., Springer, B., Thielert, W., Nauen, R., 2008. Applied aspects of neonicotinoid uses in crop protection. Pest Manag. Sci. 64, 1099-1105.

El-Gendy, K.S., Aly, N.M., Mahmoud, F.H., Kenawy, A., El-Sebae, A.K.H., 2010. The role of vitamin $\mathrm{C}$ as antioxidant in protection of oxidative stress induced by imidacloprid. Food Chem. Toxicol. 48 (1), 215-221.

Fossen, M., 2006. Environmental fate of imidacloprid. Department of Pesticide Regulation, Sacramento.

Ge, W., Yan, S., Wang, J., Zhu, L., Chen, A., Wang, J., 2015. Oxidative stress and DNA damage induced by imidacloprid in zebrafish (Danio rerio). J. Agri. Food Chem. 63 (6), 1856-1862.

Gibbons, D., Morrissey, C., Mineau, P., 2015. A review of the direct and indirect effects of neonicotinoids and fipronil on vertebrate wildlife. Environ. Sci. Poll. Res. 22 (1), $103-118$.

Goulson, D., 2014. Pesticides linked to bird declines. Nature 511, 295-296.

Guyón, N.F., Roggio, M.A., Amé, M.V., Wunderlin, D.A., Bistoni, M.A., 2016. Dynamics of Aromatase and Physiological Indexes in Male Fish as Potential Biomarkers of Anthropogenic Pollution. Bull. Environ. Contam. Toxicol. 97 (5), 632-638.

Habig, W., Pabst, M.J., Jakoby, W.B., 1974. Glutathione S-transferase, the first step in mercapturic acid formation. J. Biol. Chem. 249, 1730-1739.

Hodgson, E.K., Fridovich, I., 1975. The interaction of Bovine Erythrocyte Superoxide dismutase with $\mathrm{H} 2 \mathrm{O} 2$ inactivation of the enzyme. Biochemistry 14, 5294-5299.

International Union of Pure and Applied Chemistry, 2017. PPDB: Pesticides Properties DataBase. University of Hertforshire, Hatfield, Hertfordshire, UK. [cited 2017 November]. Available from: http://sitem.herts.ac.uk/aeru/iupac/atoz.htm.

Iturburu, F.G., Zömisch, M., Panzeri, A.M., Crupkin, A.C., Contardo-Jara, V., Pflugmacher, S., Menone, M.L., 2017. Uptake, distribution in different tissues and genotoxicity of imidacloprid in the freshwater fish Australoheros facetus. Environ. Toxicol. Chem. 36, 699-708.

Izagirre, U., Marigómez, I., 2009. Lysosomal enlargement and lysosomal membrane destabilization in mussel digestive cells measured by an integrative index. Environ. Poll. 157 (5), 1544-1553.

Kapoor, U., Srivastava, M.K., Srivastava, L.P., 2011. Toxicological impact of technical imidacloprid on ovarian morphology, hormones and antioxidant enzymes in female rats. Food Chem. Toxicol. 49 (12), 3086-3089.

Karr, J.R., 1981. Assessment of biotic integrity using fish communities. Fisheries 6 (6), 21-27.

Kookana, R.S., Correll, R.L., Miller, R.B., 2005. Pesticide impact rating index - a pesticide risk indicator for water quality. Water Air Soil Poll. Focus 5 (1-2), 45-65.

Madeira, C., Madeira, D., Diniz, M.S., Cabral, H.N., Vinagre, C., 2016. Thermal acclimation in clownfish: an integrated biomarker response and 405 multi-tissue experimental approach. Ecol. Indicators 71, 280-292.

Maggioni, T., Hued, A.C., Monferrán, M.V., Bonansea, R.I., Galanti, L.N., Amé, M.V., 2012. Bioindicators and biomarkers of environmental pollution in the middle-lower basin of the Suquía River (Córdoba, Argentina). Arch. Environ. Contam. Toxicol. 63, 337-353.

Malev, O., Klobucar, R.S., Fabbretti, E., Trebse, P., 2012. Comparative toxicity of imidacloprid and its transformation product 6-chloronicotinic acid to non-target aquatic organisms: microalgae Desmodesmus subspicatus and amphipod Gammarus fossarum. Pest. Biochem. Physiol. 104 (3), 178-186.

Masiá, A., Campo, J., Vazquez-Roig, P., Blasco, C., Picó, Y., 2013. Screening of currently used pesticides in water, sediments and biota of the Guadalquivir River basin (Spain). J. Hazard Mat. 263, 95-104.

McCord, J.M., Fridovich, I., 1969. Superoxide Dismutase. An enzymic function for 
erythrocuprein (hemocuprein). J. Biol. Chem. 244 (22), 6049-6055.

Mishra, S., Srivastava, S., Tripathi, R.D., Kumar, R., Seth, C.S., Gupta, D.K., 2006. Lea detoxification by coontail (Ceratophyllum demersum $L$.) involves induction of phytochelatins and antioxidant system in response to its accumulation. Chemosphere 65, 1027-1039.

Morrissey, C.A., Mineau, P., Devries, J.H., Sanchez-Bayo, F., Liess, M., Cavallaro, M.C. Liber, K., 2015. Neonicotinoid contamination of global surface waters and associated risk to aquatic invertebrates: a review. Environ. Internat. 74, 291-303.

Nath, S., Bose, S., Kundu, I., 2012. Effects of Thiamethoxam on Liver Protein of Oreochromis niloticus (Trewavas). Proc. Zool. Soc. 65 (2), 118-120.

Oakes, K.D., Van Der Kraak, G.J., 2003. Utility of the TBARS assay in detecting oxidative stress in white sucker (Catostomus commersoni) populations exposed to pulp mill effluent. Aq. Toxicol. 63 (4), 447-463.

Oberdorff, T., Pont, D., Hugueny, B., Porcher, J.P., 2002. Development and validation of a fish based index for the assessment of "river health" in France. Freshwater Biol. 47 (9), 1720-1734.

Oruç, E.Ö., Usta, D., 2007. Evaluation of oxidative stress responses and neurotoxicity potential of diazinon in different tissues of Cyprinus carpio. Environ. Toxicol. Pharmacol. 23 (1), 48-55.

Pain-Devin, S., Cossu-Leguille, C., Geffard, A., Giambérini, L., Jouenne, T., Minguez, L. Naudin, B., Parant, M., Rodius, F., Rousselle, P., Tarnowska, K., Daguin-Thiébaut, C. Viard, F., Devin, S., 2014. Towards a better understanding of biomarker response in field survey: A case study in eight populations of zebra mussels. Aq. Toxicol. 155, $52-61$.

Pigeolet, E., Corbisier, P., Houbion, A., Lambert, D., Michiels, C., Raes, M., Zachary, M.D., Remacle, J., 1990. Glutathione peroxidase, superoxide dismutase, and catalase inactivation by peroxides and oxygen derived free radicals. Mech. Ageing Dev. 51, 283-297.

Quintaneiro, C., Ranville, J., Nogueira, A.J.A., 2015. Effects of the essential metals copper and zinc in two freshwater detritivores species: biochemical approach. Ecotoxicol. Environ. Saf. 118, 37-46.

Revenga, C., Campbell, I., Abell, R., de Villiers, P., Bryer, M., 2005. Prospects for monitoring freshwater ecosystems towards the 2010 targets. Philos. Trans. R. Soc. London, Ser. B 360 (1454), 397-413.

Sandalio, L.M., Dalurzo, H.C., Gómez, M., Romero-Puertas, M.C., del Río, L.A., 2001. Cadmium-induced changes in the growth and oxidative metabolism of pea plants. J. Exp. Bot. 52, 2115-2126.

Santos, R., Joyeux, A., Palluel, O., Palos-Ladeiro, M., Besnard, A., Blanchard, C., Porcher,
J.M., Bony, S., Devaux, A., Sanchez, W., 2016. Characterization of a genotoxicity biomarker in three spined stickleback (Gasterosteus aculeatus L.): Biotic variability and integration in a battery of biomarkers for environmental monitoring. Environ. Toxicol. 31 (4), 415-426.

Scebba, F., Sabastiani, L., Vitagliano, C., 1998. Antioxidative enzyme activity changes in wheat (Triticum aestivum) seedlings under cold acclimation. Physiol. Plantarum 104, 747-752.

Scott, M.C., Hall, L.W., 1997. Fish assemblages as indicators of environmental degradation in Maryland coastal plain streams. Trans. Amer. Fish. Society 126, 349-360.

Serafim, A., Company, R., Lopes, B., Fonseca, V.F., França, S., Vasconcelos, R.P., Bebianno, M.J., Cabral, H.N., 2012. Application of an integrated biomarker response index (IBR) to assess temporal variation of environmental quality in two Portuguese aquatic systems. Ecol. Indi. 19, 215-225.

Sur, R., Stork, A., 2003. Uptake, translocation and metabolism of imidacloprid in plants. Bull. Insectol. 56 (1), 35-40.

Sutton, S.G., Bult, T.P., Haedrich, R.L., 2000. Relationships among fat weight, body weight, water weight, and condition factors in wild atlantic salmon parr. Trans. Amer. Fish. Society 129 (2), 527-538.

Tanaka, K., Sano, T., Ishizuka, K., Kitta, K., Kawamura, Y., 1994. Comparison of properties of leaf and root glutathione reductases from spinach. Physiol. Plant. 91 (3), 353-358.

Tišler, T., Jemec, A., Mozetič, B., Trebše, P., 2009. Hazard identification of imidacloprid to aquatic environment. Chemosphere 76 (7), 907-914.

van der Oost, R., Beyer, J., Vermeulen, N.P.E., 2003. Fish bioaccumulation and biomarkers in environmental risk assessment: a review. Environ. Toxicol. Pharmacol. 13, 57-149.

Van Dijk, T.C., Van Staalduinen, M.A., Van der Sluijs, J.P., 2013. Macroinvertebrate decline in surface water polluted with imidacloprid. PloS One 8, e62374.

Vutukuru, S.S., Chintada, S., Radha Madhavi, K., Venkateswara Rao, J., Anjaneyulu, Y., 2006. Acute effects of copper on superoxide dismutase, catalase and lipid peroxidation in the freshwater teleost fish, Esomus danricus. Fish Physiol. Biochem. 32 (3), 221-229.

West, J.D., Marnett, L.J., 2006. Endogenous reactive intermediates as modulators of cell signaling and cell death. Chem. Res. Toxicol. 19 (2), 173-194.

Wiegand, C., Pflugmacher, S., Oberemm, A., Steinberg, C., 2000. Activity development of selected detoxication enzymes during the ontogenesis of the zebrafish (Danio rerio). Intern. Rev. Hydrobiol. 85 (4), 413-422. 